\title{
Wacław Komarnicki, Polskie prawo polityczne (geneza i system), Wydawnictwo Sejmowe, Warszawa 2008, 592 strony.
}

Przed trzema laty w Kolegium Redakcyjnym „Przeglądu Sejmowego” zrodziła się inicjatywa publikacji reprintów wybranych opracowań z zakresu prawa konstytucyjnego oraz innych gałęzi prawa publicznego, które wyszły spod pióra wybitnych przedstawicieli nauki prawa Rzeczypospolitej Polskiej okresu dwudziestolecia międzywojennego. Realizacji tego pomysłu podjęło się Wydawnictwo Sejmowe, wprowadzając zaproponowane prace do swojego planu wydawniczego. Jako pierwsza, w 2008 r., opublikowana została recenzowana tutaj monografia profesora Wacława Komarnickiego ${ }^{1}$, następnie zaś opracowania profesorów Cezarego Berezowskiego ${ }^{2}$ oraz Macieja Starzewskiego ${ }^{3}$.

Wacław Komarnicki, związany z Wydziałem Prawa i Nauk Społecznych Uniwersytetu Stefana Batorego w Wilnie od chwili jego reaktywowania w 1919 r. aż do wybuchu wojny, należał do grona najwybitniejszych przedstawicieli nauki polskiego prawa konstytucyjnego Drugiej Rzeczypospolitej. Pozostawił po sobie niezwykle bogatą i wartościową, również dla współczesnych badaczy instytucji ustrojowych tamtego okresu, spuściznę naukową. W swoich licznych pracach podejmował w zasadzie wszystkie bieżące problemy organizacji i funkcjonowania państwa, będąc przy tym bardzo uważnym obserwatorem i krytycznym komentatorem dokonujących się w Polsce przeobrażeń politycznych. Sam również angażował się w działalność na forum publicznym, pełniąc z ramienia Stronnictwa Narodowego mandat poselski (w latach 1928-1935) oraz zasiadając przez dwie kadencje w Radzie Miasta Wilna. Podczas wojny Wacław Komarnicki był ministrem sprawiedliwości w emigracyjnym rządzie gen. Władysława Sikorskiego. Po jej zakończeniu pozostał w Wielkiej Brytanii, poświęcając się pracy naukowej oraz prowadząc wykłady na Polskim Wydziale Prawa Uniwersytetu w Oxfordzie ${ }^{4}$.

Monografia Polskie prawo polityczne była pierwszym w okresie międzywojennym tak obszernym studium problematyki ustroju politycznego II Rzeczypospolitej. Została napisana bezpośrednio po uchwaleniu Konstytucji marcowej z 1921 r., miała więc zarazem charakter bardzo aktualnego komentarza do przepisów tej ustawy zasadniczej. Wacław Komarnicki nie ograniczył się przy tym bynajmniej do charakterystyki ukształ-

1 Dwa lata wcześniej nakładem Wydawnictwa Uniwersytetu Jagiellońskiego wydany został reprint innej pracy Wacława Komarnickiego poświęconej systemowi ustrojowemu II Rzeczypospolitej, opublikowanej w Wilnie w 1937 r. Zob. W. Komarnicki, Ustrój państwowy Polski współczesnej. Geneza i system, Kraków 2006.

2 C. Berezowski, Powstanie państwa polskiego w świetle prawa narodów, Warszawa 2008 (reprint monografii z 1935 r.).

3 M. Starzewski, Środki zabezpieczenia prawnego konstytucyjności ustaw, Warszawa 2009 (reprint pracy wydanej w 1928 r.).

4 Profesor Wacław Komarnicki zmarł w Londynie 19 marca 1954 r. 
towanego przez tę konstytucję ustroju państwa polskiego, bowiem analizę jego instytucji ustrojowych zaprezentował na szerokim tle porównawczym. Nie można też pominąć faktu, że opracowanie to było wówczas najbardziej cenionym podręcznikiem do nauki polskiego prawa państwowego (politycznego), z którego korzystali studenci prawa aż do wejścia w życie Konstytucji kwietniowej ${ }^{5}$.

Nie sposób nie zauważyć, że w tytule oraz w treści swojego najbardziej znanego dzieła Wacław Komarnicki używa określenia „prawo polityczne”. Przypomnijmy wobec tego, że określenie to było jednym z trzech terminów (obok „prawa państwowego” oraz „prawa konstytucyjnego”), którymi posługiwano się w Polsce w okresie międzywojennym na oznaczenie dziedziny prawa obejmującej unormowania odnoszące się do podstawowych instytucji ustroju politycznego państwa. W odróżnieniu np. od Wydziału Prawa UW, gdzie obaj przedwojenni kierownicy Katedry Prawa Państwowego i Międzynarodowego (Zygmunt Cybichowski i Wacław Makowski) wykładali „prawo państwowe”, Wacław Komarnicki konsekwentnie używał na oznaczenie tej dziedziny prawa określenia „prawo polityczne”. Tak też czynili jego współpracownicy i uczniowie z Katedry Prawa Politycznego Uniwersytetu Stefana Batorego w Wilnie, w tym Andrzej Mycielski, który nawet w okresie powojennym, gdy zaczęto wykładać już tylko „prawo państwowe”, swój pierwszy podręcznik zatytułował Polskie prawo polityczne $e^{6}$.

Prezentowana tu praca składa się z dwóch części. Część pierwszą, zatytułowaną Geneza współczesnego ustroju Polski, otwierają rozważania o uwarunkowaniach międzynarodowych i prawnoustrojowych aspektach odbudowy państwa polskiego. W dalszej kolejności znalazła się rozbudowana charakterystyka ustroju politycznego Polski w okresie przejściowym, do którego Wacław Komarnicki zaliczył zarówno etap kształtowania się na ziemiach polskich centralnych ośrodków władzy pod koniec pierwszej wojny światowej, jak też okres Sejmu Ustawodawczego, czyli ustrój państwa pod rządami Małej konstytucji z 20 lutego 1919 r. Tę część monografii zamyka prezentacja trybu prac nad pełną ustawą zasadniczą, połączona z wnikliwą analizą rozwiązań ustrojowych zaproponowanych we wszystkich zgłoszonych pod obrady parlamentu projektach nowej konstytucji Rzeczypospolitej Polskiej.

W drugiej części pracy zawarty został systematyczny wykład polskiego prawa politycznego według przepisów Konstytucji RP z 17 marca 1921 r. Wacław Komarnicki podzielił go na dziewięć rozdziałów, traktujących kolejno o: konstytucyjnych zasadach ustroju państwowego (rozdział 1), Prezydencie Rzeczypospolitej (rozdział 2), Radzie Ministrów i poszczególnych członkach rządu (rozdział 3), zasadach ustroju administracyjnego Rzeczypospolitej Polskiej (rozdział 4), zasadach wyborów parlamentarnych oraz ustroju Sejmu i Senatu (rozdział 5), konstytucyjnych funkcjach i kompetencjach

5 W 1923 r. opublikowana została, w postaci skryptu dla studentów, skrócona wersja tego opracowania (W. Komarnicki, Zarys ustroju państwowego Rzeczypospolitej Polskiej, Warszawa 1923). Drugie, pełne wydanie tej monografii, istotnie zmienione i rozbudowane w porównaniu z wydaniem z 1922 r., ukazało się w 1934 r. (W. Komarnicki, Ustrój państwowy Rzeczypospolitej Polskiej, Warszawa 1934).

6 A. Mycielski, Polskie prawo polityczne, Kraków 1948. 
parlamentu (rozdział 6), ustroju sądownictwa (rozdział 7), powszechnych obowiązkach i prawach obywatelskich (rozdział 8), problematyce zmiany i rewizji konstytucji (rozdział 9). Przyjęta przez niego kolejność prezentacji kolejnych zagadnień jest więc w dużej mierze zgodna z systematyką Konstytucji marcowej, niemniej jednak dostrzec tu można jedną zasadniczą różnicę. Charakteryzując ustrój najwyższych władz Rzeczypospolitej, autor w pierwszej kolejności poświęcił swoją uwagę obu organom władzy wykonawczej (Prezydentowi i Radzie Ministrów), a dopiero później zajął się władzą ustawodawczą. Tymczasem konstytucja z 1921 r. na czoło najwyższych władz państwowych wysunęła parlament, określając jego pozycję ustrojową i podstawowe funkcje w rozdziale drugim, a więc bezpośrednio po określeniu charakteru ustrojowego państwa oraz zasady suwerenności Narodu i podziału władz w Rzeczypospolitej Polskiej.

Profesor Komarnicki dostrzegał wady przyjętego w Konstytucji marcowej systemu rządów parlamentarnych, który charakteryzowała zarysowująca się bardzo wyraźnie dominacja Sejmu w strukturze naczelnych władz państwowych Rzeczypospolitej. W ramach przyjętej przez tę ustawę zasadniczą zasady trójpodziału władz, optował on raczej za wzmocnieniem roli egzekutywy (a zwłaszcza Rady Ministrów), co miała zresztą już kilka lat później przynieść nowela sierpniowa z 1926 r. Analizując istotę i charakter ustanowionych przez konstytucję z 1921 r. rozwiązań prawnoustrojowych, Wacław Komarnicki wskazywał jednocześnie na pilną potrzebę jak najszybszego uchwalenia przez parlament określonych aktów ustawodawczych, konkretyzujących ogólne unormowania zawarte w treści konstytucji. Dostrzegał przy tym konieczność ustanowienia ustawowych gwarancji nadrzędności norm konstytucji w systemie źródeł prawa, co w konsekwencji oznaczało opowiedzenie się przez niego, podobnie jak uczynili to w tamtym okresie dwaj inni wybitni prawnicy dwudziestolecia międzywojennego, profesorowie Władysław L. Jaworski oraz Stanisław Starzyński, za ustanowieniem w Polsce instytucji sądownictwa konstytucyjnego ${ }^{7}$.

Dokonując końcowej oceny konstytucji z 1921 r. w ostatnim rozdziale monografii, Wacław Komarnicki zaznaczył, że dopiero praktyka konstytucyjna „zdecyduje, w jakie kształty przyobleką się w życiu instytucje konstytucyjne, jakimi staną się w swym działaniu, wytworzy tradycję, która uwydatni dobre strony konstytucji marcowej, osłabi zaś ujemne, wreszcie stworzy podstawę dla stopniowego udoskonalenia konstytucji w drodze jej zmian i periodycznej rewizji. Przekonani jesteśmy, że ewolucja polskiego prawa politycznego pójdzie w tym kierunku i zapewni zarówno Państwu, jak i jego obywatelom konieczne warunki rozwoju, uwzględni tak potrzeby Państwa, jak wielkie ideały ogólnoludzkie i narodowe”(s. 584-585). Te przewidywania autora nie spełniły się jednak w praktyce ustrojowej Drugiej Rzeczypospolitej, gdyż Konstytucja marcowa w swym pierwotnym kształcie obowiązywała zaledwie kilka lat, a uchwalona w 1935 r. Konstytu-

7 Zob. szerzej w tej kwestii w opracowaniu M. Granata, Problem kontroli konstytucyjności prawa w Polsce międzywojennej, [w:] Prawo konstytucyjne II Rzeczypospolitej. Nauka i instytucje, pod red. P. Sarneckiego, Kraków 2006, s. 100 i n. 
cja kwietniowa zerwała wyraźnie z zasadami systemu parlamentarnego, wprowadzając w ich miejsce model ustrojowy oparty na zasadzie jednolitej oraz niepodzielnej władzy prezydenta, czyli de facto autorytarny model rządów ${ }^{8}$.

Nie ulega wątpliwości, że ukazanie się w 1922 r. Polskiego prawa politycznego Wacława Komarnickiego było znaczącym wydarzeniem w nauce prawa II Rzeczypospolitej. Także dziś do tego dzieła sięgają historycy ustroju i prawa polskiego oraz konstytucjonaliści zajmujący się badaniem instytucji ustrojowych Polski w okresie międzywojennym. Dzięki inicjatywie Redakcji „Przeglądu Sejmowego” i opublikowaniu przez Wydawnictwo Sejmowe reprintu tej znakomitej monografii, trafi ona bez wątpienia do szerszego kręgu czytelników, dając im tym samym możliwość zapoznania się z dorobkiem jednego $\mathrm{z}$ najwybitniejszych przedstawicieli nauki polskiego prawa konstytucyjnego w XX w.

Stanisław Bożyk

8 Profesor Wacław Komarnicki zdecydowanie krytycznie oceniał już projekt Konstytucji kwietniowej, dając temu wyraz podczas wystąpienia na posiedzeniu komisji senackiej 13 grudnia 1934 r., do której został powołany w charakterze eksperta z dziedziny prawa konstytucyjnego. Wiele krytycznych uwag pod adresem tej ustawy zasadniczej zgłaszał także po jej uchwaleniu. Por. m.in. W. Komarnicki, Ustrój państwowy Polski współczesnej. Geneza i system, Wilno 1937, s. 175 i n. 